\title{
A Study on Fostering Learning Autonomy of Chinese Adult Learners in Continuing Education
}

\author{
MAN Ying \\ Beijing International Studies University, Beijing, China
}

\begin{abstract}
With the rapid growth of science and technology in the 21st century, the way people regard education has changed accordingly. The education not just aims to equip the students with a skill but most importantly to teach them how to learn, esp., how to be an autonomous learner. This paper intends to investigate the learner autonomy of Chinese adult learners by means of questionnaire and oral interview so as to find out the problems with their learning autonomy and come up with solutions.
\end{abstract}

Keywords: adult learners, learner autonomy, learner training

\section{Introduction}

With the rapid development of science and technology, the world of 21st century has really entered into an era of information explosion. The emergence and development of mass media have both made it possible for people to get to know all kinds of knowledge and information easily and conveniently. Undoubtedly, this has brought more challenges to our educational institutions, and traditional way of teaching has failed to meet the demands of the learners. In order to cater to this challenge, a series of reforms concerning educational theories, objectives as well as educational methods have to be called for. Therefore, a large number of researches in the field of foreign language teaching have been made, and the focus of research has accordingly shifted from teaching to learning, from teacher methods to learner strategies, and from teacher dependence to learner autonomy.

\section{Literature Review}

\section{Research Background of Learner Autonomy}

Over the last three decades, the idea of learner autonomy and independent learning has gained increasing attention in the field of applied linguistics in the western world. At the same time, a great number of researchers like H. Holec (1981), D. Little (1991), and L. Dickinson (1992) have all placed their researching focus on learner autonomy and its promotion. There has been more focuses on learner training, learning to learn, learner development, and learning strategies in language courses and material design, and great progress has been made in the exploration and implementation of the concept of autonomy.

Compared with the study conducted in the western countries, the research on learner autonomy in China started relatively late, in the 1990s. The research and practice about learner autonomy made its first

MAN Ying, Master of English Language and Literature, lecturer, School of English Language, Beijing International Studies University, Beijing, China. 
development in Hong Kong and several international conferences on these themes were held there in 1993 and 1994. In the early 2000s, a great number of experiments have been made in the mainland of China to foster learner autonomy. For example, Peng Jinding and his colleagues (2002) from Central South University developed the national curriculum to allow the promotion of autonomy among college students. In addition, Dong Chengru (2003) and Xu Jinfen, Peng Renzhong, and Wu Weiping (2004) analyzed the existing level of college students' autonomy, suggesting several strategies to foster learner autonomy. In spite of all the efforts made by the Chinese researchers, it seems most of the researches mentioned above have chosen undergraduates as the subjects. Very little research has been involved with adult learners in continuing education. Therefore the research over this learner community seems quite necessary.

\section{The Definition of Learner Autonomy}

One of the earliest and most frequently quoted definitions of autonomy is found in Holec's (1981, p. 3, cited in Benson, 2005) report to the Council of Europe. In his works Autonomy and Foreign Language Learning he describes autonomy as the ability to take charge of one's own learning. Taking charge of one's own learning means that the autonomous learners should have the capacity to make decisions at successive stages of the learning process. In contrast, David Little (1991, p. 4) argues learner autonomy is "essentially a matter of the learner's psychological relation to the process and content of learning - a capacity for detachment, critical reflection, decision-making, and independent action”. In Little's definition, this capacity to take responsibility for one's own learning is described more in terms of control over the cognitive processes involved in effective self-management of learning.

Other researchers such as Kenny (1993, p. 436), White (1995, p. 209), and Boud (1988, p. 17) also put forward their own definitions of learner autonomy, namely a personal characteristic, an attitude, and an approach to educational practices. So what is on earth learner autonomy? There must be a consensus over its definition. Based on the interpretations of the researchers mentioned above and the writer's personal point of view, "learner autonomy" in this paper is defined as "a process in which the learner is ready and capable of taking control of his/her learning”.

\section{The Significance of Learner Autonomy}

In literature, there has been a widespread agreement on the significance of learner autonomy. A common justification of learner autonomy both in general education and language learning is that "autonomous learners become highly motivated and that autonomy leads to better and more effective work" (Dickinson, 1992). "There is a convincing evidence that people who take the initiative in learning learn more things and learn better than do people who sit at the feet of teachers, passively waiting to be taught” (Knowles, 1975, p. 14).

Not just in western countries, the idea of learner-centeredness was already put forward in our country long time ago. Tao Xingzhi (陶行知), a great educator in Chinese history, once said, "A good teacher does not simply teach knowledge to the learners, but teach them how to learn. The purpose of teaching is not to teach". Apparently, Master Tao's idea overlaps the theory of learner autonomy and also the goal of lifelong learning, both of which advocate that the learners should learn to be independent learners free from teachers. However, due to factors of Chinese national situation and the education system, most of Chinese learners, especially language learners still remain highly teacher-dependent. Therefore, training them to be autonomous in learning is not only the need of the new era, but also a must for our country's goal of creating a lifelong learning society. 


\section{An Investigation on Chinese Adult Learners' Autonomy}

This paper aims to investigate the language learning autonomy of the adult English-major students in the Continuing Education. There are two reasons for taking them as the subjects of the research. One reason is that quite a number of researches done are concerned with the regular undergraduates of both English and non-English majors while very few studies have taken adult English majors in continuing education as subjects. The other reason is more practical. These adult students are all part-time learners. Most of the time, they are at work. So it will be of great importance to guide them onto the autonomous path of learning.

Through the investigation the writer wanted to find out the answers to four questions. They are:

1. What are the learner's general attitudes and beliefs about learner autonomy? Are they motivated to be autonomous learners?

2. Do they often employ various learning strategies to conduct their language learning? What are the strategies they usually use?

3. What is the degree to which the students monitor and evaluate their own language learning?

4. Is there any correlation between learners' language proficiency and the level of autonomous learning?

\section{Subjects}

There are altogether 52 adult English-major students who participated in this survey. They are all from the four-year undergraduate program in the School of Continuing education of BISU. They are equivalent to the second-year students in the regular colleges and universities. 46 out of the 52 students have received formal instructions in regular senior high school. In this case, they have no much difference in their background from those regular college language learners. The only difference is that most of them work during the day and come to school at night and weekend. Some of them even get married and some already have their own children. So their study time at school is very limited and they need far more time to learn by themselves. Therefore, it seems very important to learn about their level of learning autonomy.

\section{Instruments}

In order to give more accurate answers to the questions listed above, the writer of the paper adopted both quantitative and qualitative methods, i.e., the questionnaire and oral interview.

During the preliminary check of the questionnaire, one subject was found with absence of information and therefore eliminated.

The questionnaire consists of two parts. The first part is about the subjects' personal information including their age, gender, how many years they have been learning English, English scores of entrance examination for adult 4-year college program, why they choose English as their major, etc.

The second part is made up of 50 items which are divided into four groups (see Table 1) respectively concerning the students' general attitudes and beliefs towards learner autonomy (Part A), students' employment of learning strategy (Part B), students' self-monitoring of their learning process (Part C), and students' perception of teachers' roles in language teaching (Part D). 
Table 1

Structure of the Questionnaire

\begin{tabular}{lll}
\hline & Content & Number of items \\
\hline Part A & About students' general attitudes and beliefs towards autonomous learning & 6 (Item 1-Item 6) \\
Part B & About students' employment of learning strategies & 29 (Item 7-Item 35) \\
Part C & About students' monitoring of their strategy use and their control over themselves & 7 (Item 36-Item 42) \\
Part D & in the language learning process & 8 (Item 43-Item 50) \\
& About students' general perception of teacher's roles & Total: 50 \\
\hline
\end{tabular}

Paralleled with the questionnaire, an oral interview was given to some of the students' right after the questionnaires were collected. The writer randomly picked up 10 out of 51 students to participate in the interview. They were interviewed on a one-to-one basis and each of them talked with the writer for about five minutes. During the interview, the students were asked several questions which are still designed based on the four parts of the questionnaire. The questions mainly contain: (1) Why do you choose English as your major? Do you enjoy English learning? (2) What do you often do when learning independently outside classroom? (3) Do you know how to choose learning materials which suit yourself the best? (4) Do you think it necessary to learn to be autonomous in learning? (5) Do you think it necessary to take strategy-training in class? The interview, as a complement to the questionnaire, is believed to be able to help the writer better understand the students' attitudes and their implementation of their autonomous learning.

\section{Results}

The statistics show that the students' overall autonomy is at a medium level with the average score of 3.3847. Although the students have very positive attitudes and beliefs towards autonomous learning (mean = 4.0131), it seems that they do not often use various learning strategies in their autonomous learning process (mean $=3.2475$ ); that they do not often monitor their strategy use and their ability of self-control is relatively low; and that they do not have a clear perception of the teachers' roles in language teaching (mean $=3.5686$ ) (see Table 2).

Table 2

Student's Overall Level of Autonomy

\begin{tabular}{llll}
\hline Categories & Content & Mean & St. Deviation \\
\hline Part A & Students' general attitudes and beliefs towards autonomous learning & 4.0131 & 0.4771 \\
Part B & Students' employment of learning strategies & 3.2475 & 0.3246 \\
Part C & Students' self-monitoring and self-discipline over their learning process & 3.1427 & 0.2345 \\
Part D & Students' general perception of teacher's roles & 3.5686 & 0.4069 \\
& & 3.3847 & 0.3949 \\
\hline
\end{tabular}

In order to find out the relationship between learners' language proficiency and their level of autonomy, the subjects are divided into three groups (high-level, intermediate-level, and low-level) according to the English score of adult entrance examination. Ten students with scores between 120 and 132 (inclusive) are in the high-level group. Ten with scores ranging from 61 to 90 (inclusive) are regarded the low-level students. The rest 31 belong to the intermediate group with scores from 91 to 119 (inclusive). Their use of strategies is demonstrated in the Table 3. 
Table 3

The Use of Strategy by Each Proficiency Group

\begin{tabular}{llllllll}
\hline \multirow{2}{*}{ Proficiency level } & \multicolumn{7}{c}{ Mean } \\
\cline { 2 - 8 } & Metacognitive & Cognitive & Compensation & Memory & Affective & Social & 3.5594 \\
\hline High & 3.3958 & 3.4333 & 4.1333 & 3.6 & 3.45 & 3.35 & 3.3472 \\
Intermediate & 3.2879 & 3.2956 & 3.0322 & 3.3870 & 3.2257 & 2.8547 & 2.9408 \\
Low & 2.7785 & 2.7833 & 3.6333 & 3 & 2.75 & 2.7 & mean \\
\hline
\end{tabular}

Table 3 reveals a significant relationship between language proficiency and the employment of strategy use. High-level students (mean $=3.5594$ ) use various learning strategies more frequently than the intermediate-level students (mean $=3.3472$ ), who still use strategies more frequently than the low-level students (mean $=2.9408$ ). In terms of types of learning strategies, low-level students also maintain a big gap from high-level students in the frequency of strategy use.

In addition to the questionnaire, the writer also had an interview with the students to better understand the students' attitudes towards learning autonomy. The interview shows that most of the students have positive and intrinsic motivation to learn English, but they do not know what materials are suitable for them. They do not know what to do after class to improve their English level, either. They are still teacher-dependent. But it is delightful to see that the students have realized the necessity to learner autonomy. They all hope they can be autonomous learners with the help of teachers' guidance.

\section{Fostering Autonomy-A Three-Phase Training Model}

After knowing the students' attitudes and motivation to learning autonomy, the rest should lie in learner training. In order to solve this problem, the writer of the paper designs a three-phase training model, with the expectation to lead the students onto the path of learning autonomy.

\section{Phase 1-Psychological Preparation}

Psychological preparation refers to the inner state at which the students are ready for learner training of autonomy. At this stage, the teachers' training focus will be placed at helping the learners establish correct attitudes and positive motivation in autonomous learning and at raising the learners' perceived values on autonomous language learning and enhancing the learners' motivation to be autonomous, so that the students will be psychologically ready for learning autonomy.

The specific training procedures are described as follows:

1. To investigate the learners' attitudes and motivation to language learning;

2. To help learners shift their traditional belief towards language learning;

3. To tell the learners what autonomous learning is;

4. To raise learners' perceived values on autonomous learning;

5. To enhance learners' motivation to be autonomous.

In Phase 1, the teachers need to help the students establish correct attitudes and strong motivation to language learning autonomy by showing them the advantages and importance of doing so.

\section{Phase 2-Action}

The second phase is "action" stage where learners learn how to engage themselves in real autonomous learning. In order to achieve the goal of the second phase which is to make learners willing to take 
responsibility for their learning, all the work done in Phase 1 will be extremely crucial.

The training contents in this phase include three steps and they are:

1. To help learners set up their learning goals or objectives by themselves, both long-term and short-term;

2. To offer learning strategy training to learners;

3. To help enhance learners' self-monitoring ability.

Actually, the three steps are interrelated with each other and the order cannot be disturbed. Goal-setting is the prerequisite of strategy training because the former decides the latter. Self-monitoring step is one good way to check whether their strategy use is conducted well or not. However, during language teaching, the writer often finds that most of the students lack initiatives in conducting their learning, such as managing their learning time, voluntarily previewing and reviewing their lessons. Therefore, teachers have responsibility to help enhance the learners' self-monitoring ability. For example, the teachers can supervise the learners' self-monitoring process by asking them to write diary.

\section{Phase 3-Evaluation}

After the learners have been trained in strategy use and self-monitoring, they should step into last stage-learn to evaluate their own learning process. The training contents contain two steps:

1. To raise learners' awareness of self-evaluating their own learning;

2. To enhance learners' use of metacognitive strategy — evaluation.

One of the findings of the investigation shows that learners seldom initiatively evaluate their learning process. This may largely attribute to their lack of knowledge of self-evaluation. So it will be very necessary for teachers to tell them in class the importance and the necessity of evaluation. Teachers may ask the learners to write evaluating plans under which they can practice evaluation.

After the first step is done, it is time to enhance the training of learners' metacognitive strategy use. The investigation has discovered that one of the least frequently used strategy is metacognitive strategy, which is thought to be the main cause of learners' incapability in evaluating their learning process. So at this stage, students should be encouraged to evaluate their learning performances by themselves, rather than waiting for teachers to evaluate them. For example, after a student has finished his/her presentation in class, the student should be required to judge his performance by him/herself in the aspect of pronunciation, grammar, variety of sentence use, and so on. By doing so, the student will learn to reflect on his/her language output so as to become sensitive about his/her mistakes and try to correct them. Besides, learners should also be trained to evaluate a wider range of learning aspects, such as their strength and weakness in language learning and their learning strategy use.

\section{Conclusion}

In summary, learner autonomy is the process where the learners are ready and capable to take control of their own learning. As a teacher, we should try every means to help students establish confidence of being self-reliant in learning. Tao Xingzhi (陶行知), a great educator in Chinese history, once said, “A good teacher does not simply teach knowledge to the learners, but teach them how to learn. The purpose of teaching is not to teach”. Apparently, Master Tao's idea overlaps the theory of learner autonomy and also the goal of lifelong learning, both of which advocate that the learners should learn to be independent learners free from teachers. However, it is by no means easy to teach the students to be really autonomous in learning. It takes time. As 
long as the students become autonomous learners, they could better meet the needs of our modern society and the creation of a life-long society would not be an empty slogan.

\section{References}

Benson, P., \& Voller, P. (1997). Autonomy and independence in language learning. London: Longman.

Boud, D. (1988). Developing Student Autonomy in Learning. London: Kogan Page.

Dong, C. R. (2003). A Survey on Learner Autonomy in College English. Journal of Guangdong University of Foreign Studies, (4), 44-46.

Dickinson, L. (1992). Learner autonomy 2: Learner training for language learning. Dublin: Authentik.

Holec, H. (1981). Autonomy and foreign language learning. Oxford: Pergamon Press.

Kenny, B. (1993). For More Autonomy. System, 21(4), 431-432.

Little, D. (1991). Learner autonomy: Definition, issues and problems. Dublin: Authentick Language Learning Resources Ltd.

Littlewood, W. (1999). Defining and developing autonomy in East Asian contexts. Applied Linguistics, 20(1), 71-94.

Nuan, D. (1995). Closing the gap between learning and instruction. TESOL Quarterly, 29(1), 133-158.

Peng, J. D. (2002). A Study on Learner Autonomy in College English Teaching. Foreign Language World, (3), 15-19.

Wang, D. Q. (2002). On Fostering Learning Autonomy among College Students. Foreign Language World, (5), 17-23.

White, C. (1995). Autonomy and Strategy Use in Distance Foreign Language Learning: Research Findings. System, $23,207-221$.

Xu, J. F., Peng, R. Z., \& Wu, W. P. (2004). A Survey and Analysis of Learning Autonomy among College Students of Non-English Majors. Foreign Language Teaching and Research Press, (1), 64-68. 